\title{
Contributions to the systematics of Prostanthera (Labiatae) in south-eastern Australia
}

\author{
Barry J. Conn
}

\begin{abstract}
Conn, B.J. (Royal Botanic Gardens, Mrs Macquaries Road, Sydney NSW 2000, Australia) 1997. Contributions to the systematics of Prostanthera (Labiatae) in south-eastern Australia. Telopea 7(4): 319-332. Prostanthera cuneata is regarded as endemic to mainland Australia, with the type material based on cultivated material grown in Formosa garden, Tasmania. The new species Prostanthera galbraithiae B.J.Conn is here formally described. A morphological re-evaluation of Prostanthera melissifolia concludes that this species is endemic to Victoria. Prostanthera melissifolia sensu Conn, from the Northern Tablelands of New South Wales, is P. caerulea R.Br., and Prostanthera sp. aff. melissifolia sensu Beauglehole, from East Gippsland (Victoria), probably is P. incisa R.Br. (s. lat.). A full description, habitat notes, distribution map and illustration of each of the first three species are provided.
\end{abstract}

\section{Introduction}

This paper presents the conclusions of revisionary studies into the genus Prostanthera section Prostanthera, arising particularly from work towards the preparation of an account of the genus for the forthcoming Flora of Victoria, volume 4.

Terminology follows Conn (1984), except inflorescence terminology as modified by Conn (1995). Distribution information for Victoria follows Conn (1993).

\section{Distribution of Prostanthera cuneata Benth.}

Previously, Prostanthera cuneata has been regarded as occurring in New South Wales, Tasmania and Victoria. Although the type specimen of this species (Gunn 725, 7 Dec. 1842) is stated to have been collected from the 'South Esk' River, south of Launceston in Tasmania, Buchanan $(1988,1990)$ states that Gunn actually collected from 'Formosa' garden, on the estate of W.E. Lawrence, on this date. Since all other Tasmanian collections of this species are either from known cultivated specimens or their collection source is unknown, it is here proposed that the Tasmanian records of this species are probably based on cultivated material. In particular, the type is likely to have been taken from cultivated material growing at 'Formosa' garden. This species is common throughout the Snowfields region of Victoria and subalpine region of the Southern Tablelands of New South Wales.

The significance of Gunn's comments on the habitat of this species in Tasmania is unclear. In a note sent with the original collection to the Royal Botanic Gardens, Kew (as stated in Sealey 1950, p. 132), he notes that this species 'grows abundantly on the banks of the South Esk [river] about 9 miles from Launceston, which is the only place I have seen it in the colony - it grows in the poorest gravelly sand washed up by the river'. Whatever the status of the collection at the time of Gunn's collection, the absence of any extant stands leads me to conclude that it is not native or naturalised in Tasmania now. 


\section{Taxonomy}

Prostanthera cuneata Benth., in DC., Prodr. 12: 560 (1848).

J.D.Hook., Fl. Tasm. 1: 284, t. 90 (1857); F.Muell., Fragm. 6: 108 (1868); Benth., Fl. Austral. 5: 99 (1870); F.Muell., Syst. Census Austral. Pl., p. 101 (1882); Stirling, Trans. \& Proc. Roy. Soc. Victoria 21: 42 (1883); F.Muell., Key Vict. Pl. 2: 42 (1885); F.Muell., Sec. Syst. Census Austral. Pl., p. 169 (1889); C.Moore, Handb. Fl. N.S.W., p. 352 (1893); Briq., in Engl. \& Prantl, Nat. Pflanzenfam. 4(3a): 220 (1895); W.A.Dixon, Pl. New S. Wales, p. 232 (1906); Guilf., Austral. Pl., p. 302 (1911); Ewart, Fl. Victoria, p. 983 (1930); Sealy, in Curtis, Bot. Mag. 167: 132 (1950); W.M.Curtis, Fl. Tasmania 3: 554 (1967); B.J.Conn, Fl. New South Wales 3: 650 (1992).

Lectotype (here chosen): Tasmania: Cultivated at Formosa garden [not South Esk River, as stated on the BM herbarium sheet (in Gunn's hand)], R.Gunn 725, 7 Dec 1842 (BM); possible isolecto: (NSW 229615).

Usually erect, \pm compact shrub $0.5-1.5 \mathrm{~m}$ high, often becoming trailing and/or procumbent with age. Branches \pm terete, rarely subquadrangular, densely hairy throughout or within each axil to the next upper node; hairs \pm straight, patent to spreading, short, 0.05-0.2 mm long, white; glands present. Leaves dark green above, paler below, strongly aromatic (when crushed); petiole absent or to $0.5 \mathrm{~mm}$ long; lamina obovate, rarely subcircular, frequently appearing obtriangular (cuneate) when margin and apex slightly recurved, (3-)4-6(-8) long, (2.5-)3.5-5 mm wide, glabrous or with occasional hairs, particularly towards base; base subcuneate to cuneate; margin entire, rarely crenulate; apex obtuse to rounded, often appearing truncate when apex slightly recurved; venation not visible, midrib slightly raised basally. Inflorescence a frondose racemiform conflorescence, uniflorescence monadic; 4-10-flowered per conflorescence. Pherophylls not seen. Podium 1-2 mm long, glandular, although appearing glabrous, usually moderately to densely hairy, but hairs minute, to $0.5 \mathrm{~mm}$ long. Prophylls persistent, inserted just below the calyx [propodium to anthopodium ratio (1.6-)4-11], opposite, narrow, oblong or elliptic to obovate, $2.5-3.5 \mathrm{~mm}$ long, $0.7-1.5 \mathrm{~mm}$ wide, with occasional hairs, particularly on margin (hairs $0.06-0.2 \mathrm{~mm}$ long), or glabrous, glandular; base subcuneate; margin entire, \pm recurved; apex obtuse to rounded; venation faint. Calyx green, usually with purple tinge on lobes and/or adaxial surface, glabrous, except margin densely fringed with white hairs, often with hairs just extending onto inner surface at base of lobes; outer surface densely glandular basally, sparser distally; tube $2.5-3 \mathrm{~mm}$ long; abaxial lobe broadly ovate to broadly oblong, (2.2-)3-4.6 mm long, 3.2-4.3 $\mathrm{mm}$ wide at base, apex rounded to slightly emarginate, sinus to $0.1 \mathrm{~mm}$ long; adaxial lobe very broadly ovate to broadly ovate, 2.5-4 mm long, 3-4.4 mm wide at base, apex \pm rounded. Corolla 9-15 mm long, pale lavender to almost white, inner abaxial-median surface of tube with irregular row of yellow spots flanked by brownish spots or maroon-orange spots, and laterally with dark violet/purple dots; outer surface glabrous basally, distally sparsely to moderately hairy, hairs $0.1-0.2 \mathrm{~mm}$ long, spreading, antrorse to retrorse, sparsely glandular (particularly in bud); inner surface glabrous, except mouth and base of lobes sparsely hairy, hairs $0.6-0.8 \mathrm{~mm}$ long; tube (5-)6-8 mm long; abaxial median lobes very broadly spathulate, $6.5-9 \mathrm{~mm}$ long, 7-9.5 mm wide, apex irregular and rounded, usually bilobed (sinus 1.2-1.5 mm long, 1.5-2.5 mm wide distally); lateral lobes very broadly to broadly ovate, $4-5.5 \mathrm{~mm}$ long, $3.5-5.5 \mathrm{~mm}$ wide, apex rounded and slightly irregular; adaxial median lobe-pair depressed ovate to very broadly ovate, (4-)5-6 mm long, (4-)7-8.5(-10) $\mathrm{mm}$ wide [length to width ratio 0.5-0.8], apex rounded to subtruncate, slightly irregular, bilobed (sinus 1-2(-2.5) $\mathrm{mm}$ long, median margin of lobes usually touching or overlapping). Stamens inserted 1.6-2.7 mm above base of corolla; filaments 3.7-5.4 mm long; anthers 1-1.4 mm long, lobes cristate on basal 
dorsal surface (narrowly triangular trichomes $0.1-0.2 \mathrm{~mm}$ long) and with small acumen basally, connective extended to form a basal appendage 1-1.6 mm long, terminating in 1-5 narrowly triangular trichomes $0.1-0.2 \mathrm{~mm}$ long. Disc c. $0.3 \mathrm{~mm}$ long. Pistil 7.5-10 mm long; ovary cylindrical obovoid, 0.4-0.5 mm long, diameter at base $0.6-0.7 \mathrm{~mm}$, lobes $0.1-0.2 \mathrm{~mm}$ long, glands present; style $6.6-8.5 \mathrm{~mm}$ long; stigma lobes $0.5-0.6 \mathrm{~mm}$ long. Fruiting calyx not or only slightly enlarged (abaxial lobe $2.5-4 \mathrm{~mm}$ long, 3-4 mm wide; adaxial lobe 3-4 mm long, 3.5-5 mm wide). Mericarps $1.8-2 \mathrm{~mm}$ long, distally 1-1.2 mm extended beyond base of style, distal diameter 2.3-2.5 mm; seeds ellipsoid-cylindrical, 1-1.2 mm long, c. 0.5 mm diameter. Fig. 1.

Flowering: (October-) November-February (-April). Fruiting: December-March.

Distribution: this species is distributed throughout the mountainous areas of southern New South Wales (Southern Tablelands) and eastern Victoria (Snowfields). Fig. 4.

Habitat: this species usually forms a dense shrub-layer under Eucalyptus niphophila subalpine woodland or in subalpine heathland communities (at altitudes of 1500-2000 $\mathrm{m})$, on coarse sandy/gravelly soils, often peaty, frequently amongst conglomerate or granitic rocky outcrops. Associated species include Olearia phlogoppapa, Bossiaea foliosa, Orites lancifolia, Baeckea ramosissima, Phebalium squamulosum and Grevillea australis.

Notes: morphologically, this species is very homogeneous. Occasional plants in a population may have leaves that are crenulate and more rarely crenate. These plants are frequently taller than those that have entire leaves and probably represent a hybrid between $P$. cuneata and P. lasianthos. The origin of the presumed cultivated Tasmanian specimens is not known. Although, these collections tend to have narrower leaves and hairier prophylls than characteristic of most mainland populations, Porter $003 \mathcal{E}$ Conn, from the Bogong High Plains (Victoria), is somewhat similar to the Tasmanian material.

Conservation status: this widespread species is not considered to be rare or threatened.

Selected specimens examined (258 examined): New South Wales: Southern Tablelands: Mt Kosciuszko National Park: Charlotte Pass, Ashby 2825, 3 Mar 1969 (AD 97120306); summit of Mt Bimberi, Darbyshire 122, 17 Jan 1961 (BRI 79384, CANB 89036, K, MEL 43027, NSW 229116); on road between Mt Gingera and Blackfellows Gap, Darbyshire 155, 15 Feb 1961 (BM, CANB 90406).

Victoria: Snowfields: near summit of Mt Stirling, Corrick 7949, 30 Jan 1982 (MEL 602631); Mt Buffalo plateau, Hill 1268, 31 Dec 1963 (AD 96410034); ascent from Dargo to Hotham Heights Phillips 63, without date (AD 97329180, CBG 046274); eastern slopes of Rocky Valley Dam catchment, Bogong High Plains area, Porter 003 \& Conn, 18 Dec 1987 (NSW 196966).

\section{Presumed cultivated Tasmanian material}

Tasmania: Midlands: s. loc., Ex W.H. Archer herb. s.n., without date (NSW 134359); Cultivated, Hobart Government Gardens, originally from Launceston, Gunn 725/1842, 3 Feb 1840 (HO 7279); s. loc. [?Formosa Garden at W.E. Lawrence estate], Gunn 725/1842, anno 1842 (NSW 229615); Formosa garden [not South Esk River], Gunn 725/1842, 7 Dec 1842 (HO 7278; NSW 134505); Formosa garden, Gunn 725/1842, 5 Dec. 1848 (NSW 134537); Perth [suburb of Launceston, presumed cultivated], Rodway s.n., without date (HO 12925, NSW 231162); South Esk River, ?C. Stuart s.n., 10 Dec 1851 (MEL 43031); Van Diemensland, C. Stuart s.n., without date, (LUND, MEL 43029).

\section{Prostanthera galbraithiae}

Prostanthera galbraithiae B.J.Conn, sp. nov.

Prostanthera sp. aff. linearis R.Br. sensu Beauglehole, Victorian Vasc. Pl. Checkl. (1980)173.

Frutex erectus effusus 0.1-2 m altus. Rami plus minusve transverse quandrangulati, dense tomentosi, pilis antrorsis adpressis, $0.1-0.3 \mathrm{~mm}$ longis, sparsim glandiferi. Folia sessilia, plerumque glabra, sparsim glandifera; lamina anguste ovata vel oblonga, 


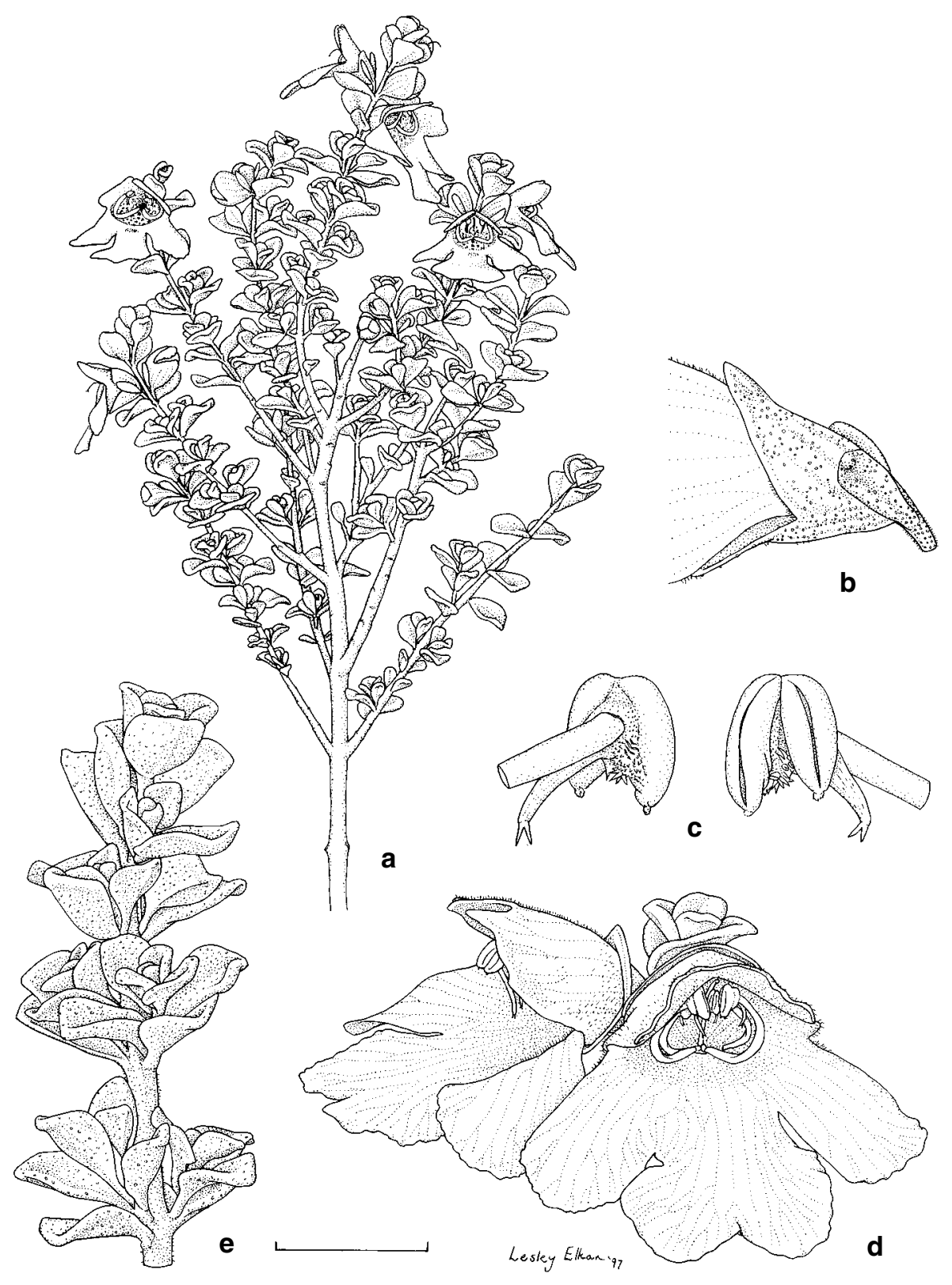

Fig. 1: Prostanthera cuneata Benth. a, Flowering branchlet; $\mathbf{b}$, detail of calyx and prophylls; c, stamens with basal appendage, showing ventral and dorsal views; $\mathbf{d}$, open flower showing stamens and gynoecium; e, detail of branchlets showing the typically crowded leaves. (a Gittins 432; b-e Porter 003 \& Conn). Scale bar: $\mathrm{a}=30 \mathrm{~mm} ; \mathrm{b}=4 \mathrm{~mm} ; \mathrm{c}=2 \mathrm{~mm} ; \mathrm{d}=6 \mathrm{~mm}$; $=6.7 \mathrm{~mm}$. 
(5-)8-15(-25) mm longa, ad $2 \mathrm{~mm}$ lata, basi subobtusa, margine integro plus minusve valde revoluto, apice plus minusve obtuso. Podium 1.5-2.3 mm longum. Prophylla $2-2.5 \mathrm{~mm}$ longa, 0.4-0.6 mm lata. Calyx extra sparsim ad moderate tomentosus, tubo 2-2.5 mm longo, lobi 2-3 mm longi. Corolla permalvina ad purpurea punctis marroninis, $7-10 \mathrm{~mm}$ longa, glaber, tubo 3-3.5 mm longo, lobo abaxiali-mediano late obovato ad leviter spathulato, $4.2-4.5 \mathrm{~mm}$ longo, lobis lateralibus late oblongis ad leviter late obovatis, 3.5-3.8 mm longis, lobo adaxiali-mediano depresse obovato ad perdepresse ovato, $3.5-5 \mathrm{~mm}$ longo. Antherae 1.2-1.5 mm longae, appendice absens. Pistillum 5.5-6 mm longum. Mericarpia non visa.

Holotype: Victoria: Gippsland Plains: Holey Plains State Park, Conn 2486 E Corrick, 14 Oct 1986 (MEL 1552450); isotype: NSW 451472.

Erect or spreading subshrub or shrub, 0.1-2 $\mathrm{m}$ high. Branches \pm transversely quadrangular in section, slightly laterally 2-ridged, especially on young branchlets, densely hairy [100-160 hairs $\left./ \mathrm{mm}^{2}\right]$ between ridges and at nodes, otherwise glabrous; hairs antrorse, appressed, $0.1-0.3 \mathrm{~mm}$ long, white; glands scattered and usually very sparse. Leaves mid green, \pm aromatic (when crushed), sessile, hence petiole absent; lamina very narrowly ovate or oblong, appearing \pm linear because margin strongly revolute, (5-)8-15(-25) $\mathrm{mm}$ long, up to $2 \mathrm{~mm}$ wide [length to width ratio up to c. 13 , length of maximum width from base to total lamina length ratio up to c. 0.1], glabrous, rarely with an occasional minute hair, sparsely glandular; base subobtuse; margin entire, \pm strongly revolute; apex \pm obtuse; venation indistinct, midrib slightly raised on abaxial surface. Inflorescence a frondose metabotryoidal conflorescence, uniflorescence racemiform, 8-24-flowered. Podium 1.5-3 mm long, densely hairy (similar to branchlets) or glabrous. Prophylls persistent, inserted just below the calyx [propodium $1.2-3 \mathrm{~mm}$ long; anthopodium $0.2-0.5 \mathrm{~mm}$ long; propodium to anthopodium ratio 6-7.5], opposite, narrowly elliptic, $2-2.5 \mathrm{~mm}$ long, $0.4-0.6 \mathrm{~mm}$ wide [length to width ratio c.5], glabrous or with a few scattered hairs near base at apex, not glandular; margin entire; apex obtuse; venation not visible. Calyx green abaxially, maroon adaxially; outer surface sparsely to moderately hairy, especially on abaxial surface of tube and on abaxial lobe, including margin of both lobes, adaxial surface (including lobe) usually glabrous, with hairs white, appressed, antrorse, c. $0.1 \mathrm{~mm}$ long, sparsely glandular; tube 2-2.5 mm long, with inner surface glabrous except for a few scattered hairs at mouth (hairs \pm patent, to $0.1 \mathrm{~mm}$ long); lobes with inner surface densely hairy distally, with \pm spreading hairs to c. $0.1 \mathrm{~mm}$ long; abaxial lobe very broadly ovate, $2-3 \mathrm{~mm}$ long, 2.4-3 $\mathrm{mm}$ wide at base [length to width ratio $0.7-1$ ], apex rounded; adaxial lobe very broadly ovate, $2-3 \mathrm{~mm}$ long, $3.3-4 \mathrm{~mm}$ wide at base [length to width ratio 0.6-0.8], apex obtuse [adaxial lobe length to abaxial lobe length ratio 0.8-1]. Corolla 7-10 mm long, deep mauve to purple with maroon dots at base of lobes and in mouth and throat, glabrous, glands absent; tube 3-3.5 mm long; abaxial median lobes broadly obovate to slightly spathulate, $4.2-4.5 \mathrm{~mm}$ long, $3.5-5 \mathrm{~mm}$ wide [length to width ratio 0.8-1.3], apex slightly irregular and rounded, usually bilobed (sinus to $0.5 \mathrm{~mm}$ long, 1-1.5 mm wide distally); lateral lobes broad, oblong to slightly obovate, $3.5-3.8 \mathrm{~mm}$ long, 3.2-3.5 mm wide [length to width ratio 1-1.2]), apex rounded to almost truncate, slightly irregular; adaxial median lobe-pair depressed obovate to very depressed ovate, $3.5-5 \mathrm{~mm}$ long, 6.5-7 mm wide [length to width ratio 0.5-0.7], apex rounded, irregular, bilobed (sinus to $3.5 \mathrm{~mm}$ long, median margin of lobes usually touching or overlapping). Stamens inserted 2-2.2 mm above base of corolla; filaments $1.6-2 \mathrm{~mm}$ long; anthers 1.2-1.5 mm long, distinctly papillate, lobes with a few narrowly triangular trichomes c. $0.1 \mathrm{~mm}$ long on basal dorsal surface and usually with small acumen basally, connective lacking basal appendage. Disc c. $0.2 \mathrm{~mm}$ long. Pistil $5.5-6 \mathrm{~mm}$ long; ovary cylindrical obovoid, 0.4-0.5 mm long, diameter at base $0.5-0.6 \mathrm{~mm}$, lobes 0.1-0.2 mm long, glands present; style c. $6 \mathrm{~mm}$ long; stigma lobes c. $0.3 \mathrm{~mm}$ long. Mature fruits not seen. Fig. 2. 
Selected specimens examined (6 examined): Victoria: Gippsland Plains: c. $4 \mathrm{~km}$ SE of Dutson Downs and c. $500 \mathrm{~m}$ SW of track from Dutson Downs to the Ninety Mile Beach, Conn $2485 \mathcal{E}$ Corrick, 14 Oct 1986 (MEL 1552449); Dutson Downs, $135 \mathrm{~m}$ from junction of track to Lake Reeve, Robinson s.n., 10 Oct 1986 (MEL 1552737); Holey Plains State Park, Chessum Road, 0.2 km W of Kellys Road, Conn 2487 \& Corrick, 14 Oct 1986 (CHR, MEL 1552448, NSW 451473, RSA); 200 m E of fire tower on summit of Holey Hill, Walsh 1615, 1 Oct 1986 (MEL, NSW 206771).

Distribution: this species is restricted to the Dutson Down-Holey Plains State Park region, Gippsland Plains, Victoria. Fig. 4.

Habitat: this species occurs in sandy soils, often quartz-rich or gravelly, overlying clays. This substrate supports an open Eucalyptus obliqua woodland community, with a heathland understorey dominated by Leptospermum myrsinoides, Acacia oxycedrus, Epacris impressa, Lepidosperma concavum and Platylobium obtusangulum. In more disturbed sites the ground layer is often dominated by bracken fern.

Etymology: the specific epithet honours Jean Galbraith who was one of the first people to discover this species and to recognise its vulnerability from inappropriate management procedures. Jean has made a significant contribution to our understanding of the flora of Victoria, particularly in association with the Latrobe Valley Field Naturalists Inc. Her efforts have directly resulted in the protection of the 'Wildflower Track' population of this species by the then Forestry Commission.

Notes: this species is characterised by having sessile, very narrowly ovate or oblong leaves that are more or less strongly revolute, corolla with abaxial median lobe approximately the same width as the lateral lobes, and distinctly papillate anthers that lack an appendage. The affinities of this species are uncertain, but it appears to have closest affinities with the $P$. saxicola group.

Conservation status: although the conservation status of Prostanthera galbraithiae is unknown, individual plants are sometimes locally common, especially after fire. However, most populations appear to be only represented by a few, scattered plants. Some populations appear to have been lost in recent years (Thompson, pers. comm. 26 March 1997; Walsh, pers. comm. 26 March 1997). The complete exclusion of disturbance (eg. fire) appears to be detrimental to the species, as observed at the 'Wildflower Track' reserve.

\section{Systematics of Prostanthera melissifola F.Muell. (s. str.)}

During the preparation of an account of the genus for the Flora of New South Wales project (Conn 1992), collections from northern New South Wales were incorrectly referred to Prostanthera melissifolia. Subsequent research has revealed that this species is endemic to Victoria, with the above collections from New South Wales redetermined as $P$. caerulea (further discussed below).

\section{Taxonomy}

Prostanthera melissifolia F.Muell., Fragm. 1: 19 (1858); 1: 242 (1859); Benth., Fl. Austral. 5: 95 (1870); F.Muell., Syst. Cens. Austral. Pl., p. 101 (1882); Sullivan in Wing, S. Sci. Rec. 3: 215 (1883) [as Prostanthera mellissifolia]; F. Muell., Key Vict. Pl. 2: 42 1885); 1: 386 (1887); Sec. Cens. Austral. Pl., p. 169 (1889); Briq. in Engl. \& Prantl, Nat. Pflanzenfam 4(3a): 221 (1895); Guilf., Austral. Pl., p. 305 (1911); Ewart, Fl. Vict., p. 985 (1930); Worsdell, Index Lond. Suppl. pt. II(I-Z), p. 276 (1941); Althofer, Cradle of Incense, pp. 70, $72 \& 73$ (1978).

Lectotype (here chosen): Victoria: 'Upper Barwan [Barwon River] of Apollo Bay', F. Mueller s.n., s. dat. (MEL 43368); probable isolecto.: (MEL 43367, 43369 \& 43370). (refer Typification) 


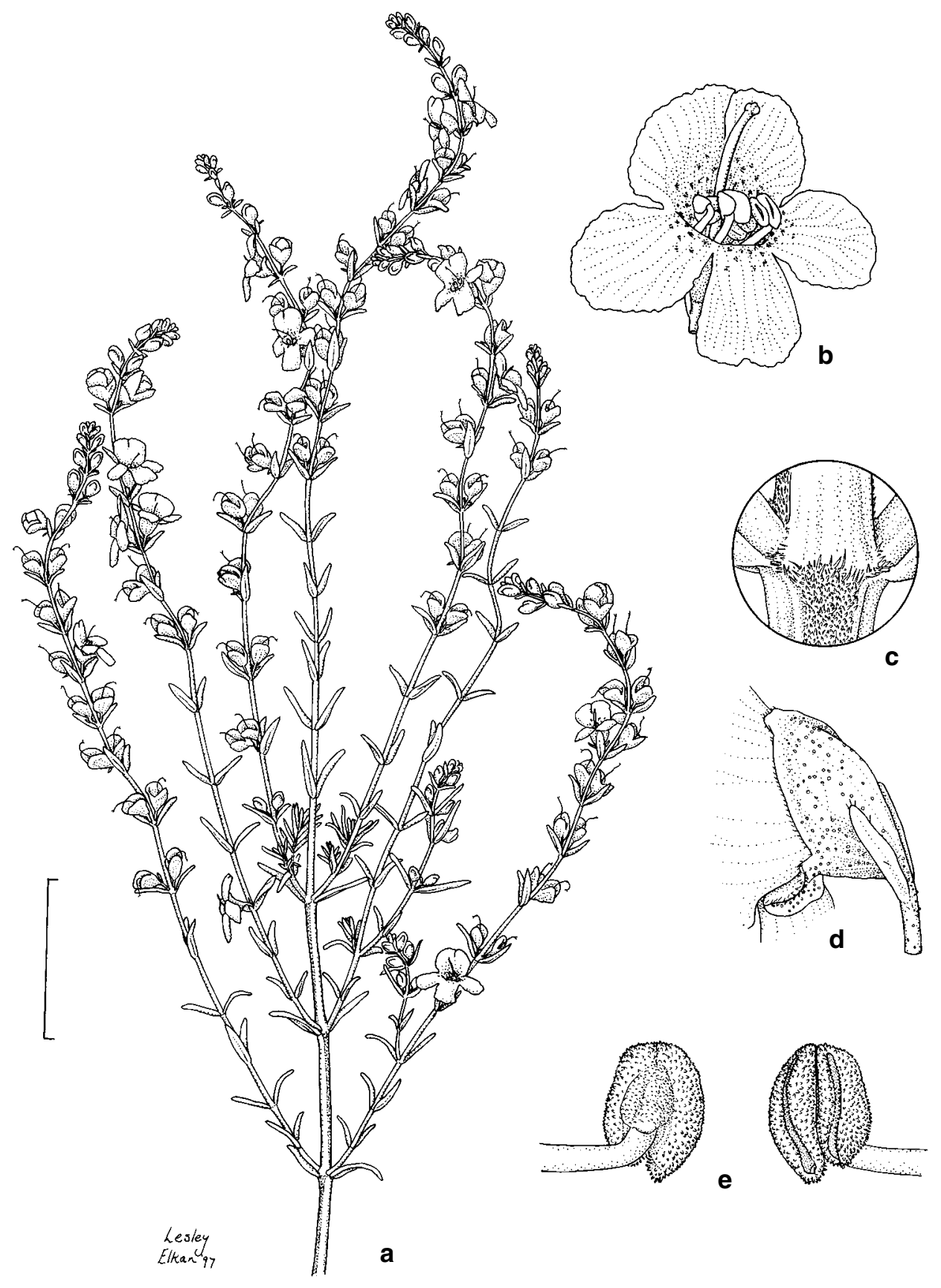

Fig. 2: Prostanthera galbraithiae B.J. Conn. $\mathbf{a}$, Flowering branchlet; $\mathbf{b}$, open flower showing stamens and gynoecium; c, detail of branchlets at node showing indumentum; d, lateral view of calyx, with detail of prophylls and propodium; e, ventral stamen, showing dorsal surface and connective(left) and ventral surfaces; $(\mathrm{a}-\mathrm{e}$ Conn 2488). Scale bar: $\mathrm{a}=30 \mathrm{~mm} ; \mathrm{b}=6 \mathrm{~mm} ; \mathrm{c}=3 \mathrm{~mm} ; \mathrm{d}=4 \mathrm{~mm} ; \mathrm{e}=2 \mathrm{~mm}$. 
P. melissifolia F. Muell. var. parvifolia Sealy, in Cotton, Curtis's Bot. Mag. 164(1948) t. 9687.

Iconotype (here chosen): Plate 9687, in Cotton, Curtis's Bot. Mag. 164(1948). (refer Typification)

Erect shrub to small tree, 1-5 m high. Branches subquadrangular, often with 2 pairs of lateral ridges, or terete, sparsely to moderately hairy particularly along lateral ridges and at nodes; hairs white, \pm antrorse to slightly spreading, \pm curled, c. $0.2 \mathrm{~mm}$ long; sparsely to moderately glandular. Leaves dark-green above, paler below, slightly and faintly unpleasantly aromatic, densely glandular; petiole (8-)10-15 mm long, usually deeply grooved adaxially, moderately to densely hairy (hairs as for branches); lamina ovate to narrowly ovate, rarely elliptic, $12-50(-60) \mathrm{mm}$ long, 9-25(-30) $\mathrm{mm}$ wide [length to width ratio 1.2-2(-3)]; base attenuate, \pm assymetric; margin toothed, rarely entire; teeth directed forward (0.5-1 mm long, $0.5-1 \mathrm{~mm}$ wide at base), 2-7 pairs of teeth, or teeth absent; apex obtuse; venation distinct, midrib and veins raised on abaxial surface; almost glabrous, except abaxial midrib and basal part of margin moderately to densely hairy (hairs as for branches), with adaxial midrib usually more sparsely hairy. Inflorescence a bracteose tribotryoidal to many-botryoidal conflorescence, occasionally botryoidal, uniflorescence a botryoid; (4-)10-20-flowered [per uniflorescence]. Pherophylls not persistent, broadly to narrowly ovate (apex appearing abruptly tapered when margin incurved), c. $2 \mathrm{~mm}$ long, c. $1 \mathrm{~mm}$ wide [length to width ratio 1.1-3.3], moderately hairy, with margin fimbriate (hairs c. $0.1 \mathrm{~mm}$ long), densely glandular; venation indistinct. Podium 2-3 mm long, moderately hairy (hairs as for branches), densely glandular. Prophylls usually maroon, persistent, inserted just below the calyx [propodium to anthopodium ratio c. 10], opposite, linear, 1-1.5 mm long, c. $0.1 \mathrm{~mm}$ wide [length to width ratio 6-10]; moderately hairy particularly along margin, moderately glandular; margin entire, incurved; apex obtuse; venation not visible. Calyx green, often with maroon tinge; outer surface sparsely hairy particularly on margin and between base of lobes (hairs as for branches), very densely glandular; inner surface glabrous; tube $1.8-2.3 \mathrm{~mm}$ long; abaxial lobe very broadly ovate to ovate, $1.5-2.5 \mathrm{~mm}$ long, $2-2.3 \mathrm{~mm}$ wide [length to width ratio 0.7-1.3], apex rounded, occasionally slightly emarginate; adaxial lobe depressed ovate to oblong, $1.5-2.5 \mathrm{~mm}$ long, $2.5-3 \mathrm{~mm}$ [length to width ratio $0.6-1$ ], apex rounded [adaxial lobe length to abaxial lobe length ratio c. 1]. Corolla (8-)10-12 mm long, dark mauve, occasionally pinkish, markings absent; outer surface glabrous near base, sparsely to moderately hairy distally (hairs as for branches), sparsely glandular; inner surface glabrous, except margin of lobes fimbriate (hairs \pm tangled, $0.1-0.3 \mathrm{~mm}$ long), or sparsely to moderately hairy on lobes; tube abruptly broadly campanulate (collar-like at base), 5-6 mm long; abaxial median lobes \pm circular to obovate, $5.5-7 \mathrm{~mm}$ long, 5-6 mm wide [length to width ratio 1-1.2], apex rounded, often slightly irregular, slightly bilobed (sinus to $0.3 \mathrm{~mm}$ long, to $2 \mathrm{~mm}$ wide distally); lateral lobes ovate, $4.2-6 \mathrm{~mm}$ long, 4.8-6 mm wide [length to width ratio 0.9-1], apex slightly irregular, rounded to slightly retuse; adaxial median lobe-pair depressed ovate, 3-3.5 $\mathrm{mm}$ long, 7-8 $\mathrm{mm}$ wide [length to width ratio c. 0.3], apex rounded, irregular, bilobed (sinus 3-3.5 mm long, $2.5-3 \mathrm{~mm}$ wide). Stamens inserted $1-1.5 \mathrm{~mm}$ above base of corolla; filaments $2.5-3 \mathrm{~mm}$ long; anthers dark purple, 1.2-1.5 mm long, lobes cristate on basal dorsal surface (trichomes narrowly triangular, $0.1-0.2 \mathrm{~mm}$ long) and with small acumen basally 0.1-0.2 $\mathrm{mm}$ long, basal appendages 1 or 2 per locule (usually with 1 undeveloped), to $0.5 \mathrm{~mm}$ long, frequently appearing absent, frequently with narrowly triangular trichomes distally. Disc c. $0.2 \mathrm{~mm}$ long. Pistil $8-10.5 \mathrm{~mm}$ long, often glandular; ovary cylindrical obovoid, $0.4-0.6 \mathrm{~mm}$ long, diameter at base $0.2-0.4 \mathrm{~mm}$, lobes $0.1-0.2 \mathrm{~mm}$ long; style lilac, 7-10 mm long; stigma lobes $0.3-0.4 \mathrm{~mm}$ long (to $0.8 \mathrm{~mm}$ long in fruit). Fruiting calyx slightly enlarged (abaxial lobe $4-4.5 \mathrm{~mm}$ long, 4-4.5 mm wide [length to width ratio 0.9]; adaxial lobe $4.5-5 \mathrm{~mm}$ long, $5.5-6 \mathrm{~mm}$ wide [length to width ratio 0.8-0.9]; [adaxial lobe length to abaxial lobe length ratio 1-1.3]). Mericarps $1.8-2 \mathrm{~mm}$ 
long, distally c. $1 \mathrm{~mm}$ extended beyond base of style, distal diameter 2-2.5 mm; seeds ellipsoid-cylindrical, c. $1 \mathrm{~mm}$ long, c. $0.5 \mathrm{~mm}$ diameter. Fig. 3.

Distribution: this species is here regarded as endemic in Victoria, occurring from the Otway Ranges (in the west), Eastern Highlands, Gippsland Highlands, Snowfields and (doubtfully) East Gippsland (in the east)(see Notes, below). Fig. 4.

Flowering: November-January (-April). Fruiting: December-January (-June). Last season's old fruits frequently persist on the plant.

Vernacular name: Balm Mint-bush (Willis 1973, p. 588).

Notes: the leaves of this species are morphologically variable. However, local populations are usually relatively homogeneous, except that smaller leaves frequently occur on the distal end of branches (particularly near inflorescence). In general, at higher altitudes, there is a reduction in leaf size, such as near Lake Mountain (Forbes 1909) and Powelltown (Muir 955 - MEL 48250). However, plants with smaller leaves occur within populations of otherwise normal leaf-sized plants (eg. near Foster, Beauglehole 63002, between Toora and Gunyah, Willis E Smith s.n., and two plants seen (one destroyed) from near Creswick, Hateley s.n.). Since Prostanthera melissifolia var. parvifolia is merely one of these small leaf variants, it is here reduced to the synonymy of $P$. melissifolia. The leaf margin is variously toothed, varying between leaves of a single plant, within-populations (Muir 955 - NSW 253733) or between-populations. Detailed population studies are required to evaluate the taxonomic status of this latter collection. However, apart from the leaf-margin, all other features are typical of $P$. melissifolia.

Although this species has been once recorded as occurring in the You Yangs (Midlands, Victoria)(Walter s.n.), it no longer appears to occur there. It is possible that this locality is incorrect.

Whether or not P. melissifolia occurs in East Gippsland is not known. One collection (Willis $\mathcal{E}$ Beauglehole s.n.) from the Howe Range has ovate leaves with somewhat oblique leaf bases more characteristic of the nominate variant from the Otways Range. Since Willis' locality information is usually accurate, this collection is anomalous. For a discussion of the typical Howe Range populations, previously regarded as P. sp. aff. melissifolia, refer to P. incisa R.Br. s. lat. (below).

Typification: although the four Mueller collections of Prostanthera melissifolia, as held at MEL, are from the same locality, MEL 43368 is here chosen as the lectotype because it has several flowers (with corolla and anthers intact) remaining on the collection. The other collections (cited above) have fewer flowers (corolla and anthers intact) or flowers with only calyx and gynoecium remaining.

Unfortunately, there appears to be no herbarium material of P. melissifolia var. parvifolia. This material was originally introduced to the Royal Botanic Gardens, Kew in 1929 as P. sieberi, from material cultivated in New Zealand (Sealy 1948). Since the illustrations (t. 9687) included with the protologue are sufficient to circumscribe this taxon, these are chosen as the iconotype.

Habitat: throughout much of it range, this species is commonly associated with openings in the forest, particularly along roads, and margin of Open Tall Eucalyptusdominated (Wet Sclerophyll) forest, at altitudes of 250-700 m. The dominant eucalypts are usually Eucalyptus obliqua or E. regnans. The understorey typically consists of Hedycarya angustifolia, Bedfordia arborescens, Cyathea australis, Dicksonia antarctica, Olearia lirata, Polyscias sambucifolia, Acacia dealbata, and Pomaderris spp. 




Fig. 3: Prostanthera melissifolia F.Muell. a, Flowering branchlet; b, branchlet showing smaller leaves with slightly attenuate lamina bases; c, branchlet showing smaller leaves with more rounded lamina bases; $\mathbf{d}$, branchlet with larger leaves and young infructescence; $\mathbf{e}$, detail of calyx, prophylls and propodium in bud; f, ventral stamen, showing ventral surface (left) and dorsal surface and connective (right); $g$, open flowers showing stamens and gynoecium; $\mathbf{h}$, detail of indumentum and sessile glands on branchlet; $\mathbf{i}$, indumentum on margin of corolla lobes. $(\mathrm{a}, \mathrm{e}-\mathbf{i}$ Conn 3044; b Forbes 1909; c Nordenstam \& Anderberg 1187; d Mueller s.n., MEL 43368). Scale bar: a-d $=30 \mathrm{~mm} ; \mathrm{e}=4 \mathrm{~mm} ; \mathrm{f}=2 \mathrm{~mm} ; \mathrm{g}=6 \mathrm{~mm} ; \mathrm{h} \& \mathrm{i}=1.2 \mathrm{~mm}$. 
Selected specimens examined (c. 90 examined). Victoria: Snowfields: Lake Mountain Road, near Kellys Plain, Forbes 1909, 21 Dec 1983 (MEL 665262, NSW 410716); ?East Gippsland: Howe Range, Willis \& Beauglehole s.n., 2 Nov 1969 (MEL 43371)(refer Notes, above); Eastern Highlands: 0.9 km (by road) S of Dom Dom Saddle, Black Spur on Maroondah Highway, Conn 3044, 11 Nov 1988 (AD, KUN, MEL, NSW 218450, NY); Above Ada River, c. 6 miles NE of Powelltown, Muir 955, 13 Dec 1959 (MEL 48250, NSW 253773); Gippsland Highlands: Bulga National Park, Carrick 3322, 23 Jan 1973 (AD 97331154); Grand Ridge Road, 1 km W of Dingoes Creek Road, 19 km NE of Forster Post Office, Beauglehole 63002, 21 Dec 1978 (MEL); Grand Ridge Road, 4 km E of English Corner, Walsh 190, 22 Nov 1978 (MEL 547864); Between Toora and Gunyah, S. Gippsland, Willis \& Smith s.n., Nov 1951 (MEL 43373); Midlands: Creswick Plantations, Hateley s.n., Feb 1986 (MEL 1546704); You Yangs, Walter s.n., Oct 1892 (NSW 134088); Otway Range: Mt Sabine, on road to Forest, Melville 3196, 27 Feb 1953 (MEL 1554255, NSW 253676).

\section{Status of Prostanthera melissifolia sensu Conn (1992)}

Prostanthera melissifolia F.Muell. sensu B.J.Conn, Fl. New South Wales 3: 655, 656 (1992) non F.Muell. (1858) = Prostanthera caerulea R.Br. (refer 'Orthography', below)

Notes: Morphologically, Prostanthera caerulea and P. melissifolia are superficially very similar, with both having similar indumentum on branchlets, densely glandular calyces, and variously mauve corollas that lack markings. The leaf lamina of P. caerulea is usually narrowly ovate (occasionally ovate), $18-65 \mathrm{~mm}$ long, 6-22 mm wide [length to width ratio $c .3$ ], with base cuneate to narrowly obtuse, symmetric, and petiole $2-12 \mathrm{~mm}$ long; whereas that of $P$. melissifolia is ovate to narrowly ovate, rarely elliptic, $12-50(-60) \mathrm{mm}$ long, 9-25(-30) $\mathrm{mm}$ wide [length to width ratio 1.2-2(-3)], with base attenuate, more or less asymmetric, and petiole (8-)10-15 mm long. In P. melissifolia, the prophylls are

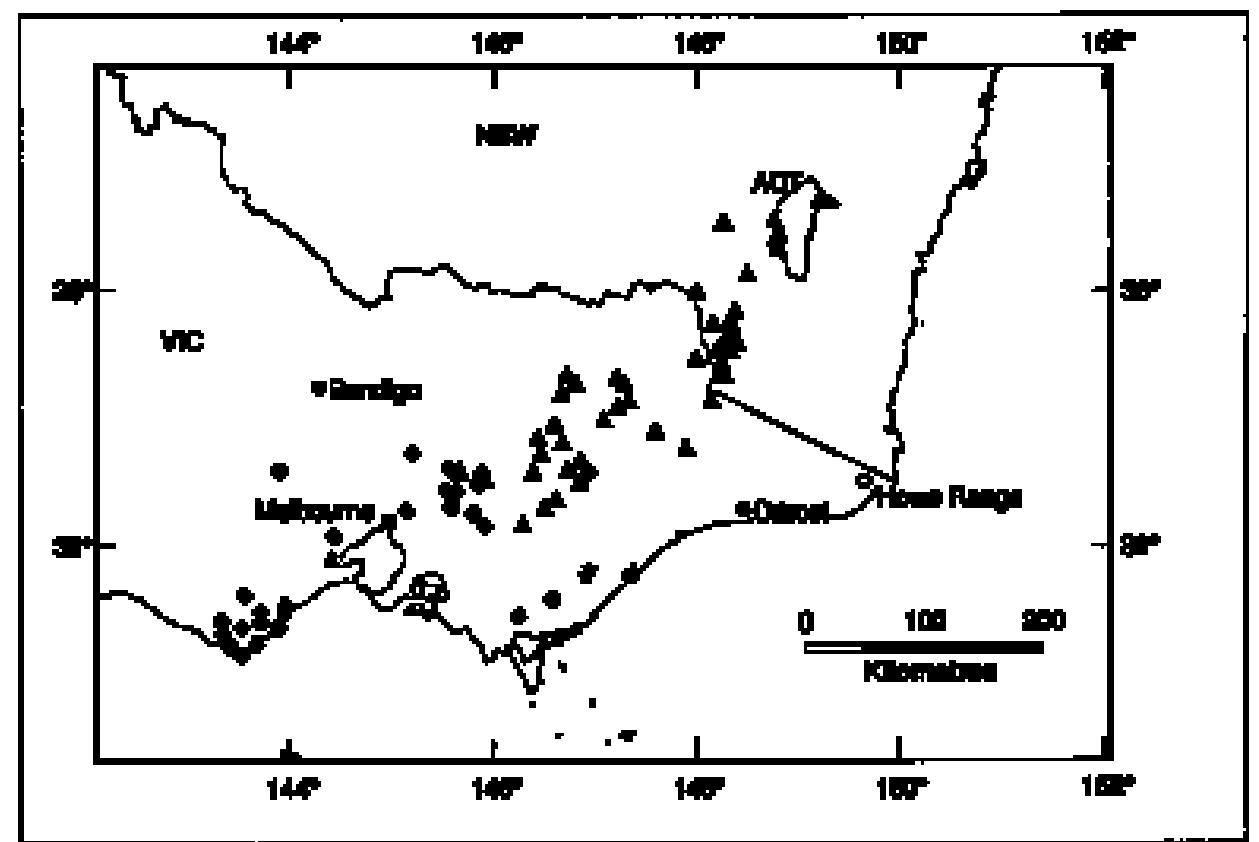

Fig. 4: Distribution of species in Victoria and south-eastern New South Wales; Prostanthera cuneata (solid triangle); P. galbraithiae (solid star); P. melissifolia (open diamond). Note: open circle refers to locality of the Howe Range. 
persistent, 1-1.5 mm long, c. $0.1 \mathrm{~mm}$ wide (cf. in P. caerulea, not persistent, $2.5-3 \mathrm{~mm}$ long, c. $0.5 \mathrm{~mm}$ wide). The stamens of $P$. melissifolia lack anther appendages, whereas although appearing to be absent in $P$. caerulea they are only c. $0.5 \mathrm{~mm}$ long. Prostanthera caerulea is an erect shrub, 0.5-3 m high, that flowers in spring (from September to November), whereas $P$. melissifolia is an erect shrub to small tree, $1-5 \mathrm{~m}$ high, flowering in summer (from November to January, rarely to April). Prostanthera caerulea occurs from southern Queensland to the Northern Tablelands, Central Tablelands, North Coast and Central Coast regions of New South Wales.

Orthography: there has been some confusion as to the correct spelling of Prostanthera caerulea. In the protologue, Brown (1810, p. 508) used the diphthong ' $æ$ 'in the specific epithet, namely 'crrulea'. However, confusion has occurred because the italicisation of

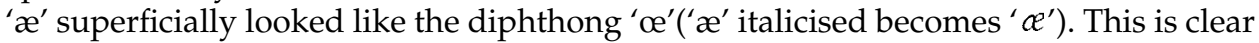
from Brown's use of ' $æ$ ' in 'Anther $\varkappa^{\prime}$ in the protologue. For a distinction between italicised and non-italicised ' $æ$ ' diphthong refer Fowler (1965: 12). Bentham (1834, p. 450) was the first to inadvertently convert ' $æ$ ' to 'œ' (as 'CEERULEA'), and later by Mueller (1867: 106)(as 'cœrulea') and again by Bentham (1870: 94)(as 'coerulea'). More recently, Chapman (1991) followed Bentham's (1870) spelling of the epithet, rather than the entry in Index Kewensis (Hooker \& Jackson 1894: 630).

5. Prostanthera incisa R.Br., P. violacea sensu Ewart (1931), and P. sp. aff. melissifolia sensu Beauglehole (1980)

Ewart (1931) identified collections of Prostanthera from Cape Howe and Cann River (both East Gippsland) as P. incisa R.Br. and P. violacea R.Br., respectively. Although Willis (1973) excluded these two species from the flora of Victoria, he did not indicate which species these collections belonged to. However, he did suggest that the reference to $P$. violacea was based on 'an erroneous record' (Willis 1972, p. 590). Likewise, the validity of the reference to P. violacea var. albiflora [F.Muell.] (Ewart 1931, p. 984) is unknown because no collections are referred to this taxon. Subsequently, the affinities of the Howe Range material have been placed with P. melissifolia (as P. sp. aff. melissifolia, Beauglehole 1980). Although there is some doubt about the true identity of the Howe Range collections, it is here concluded that they are best regarded as part of P. incisa R.Br. sensu lato (as applied by Conn 1992).

\section{Taxonomy}

The following description is provided to assist in the recognition of the East Gippsland populations here referred to this taxon.

Prostanthera incisa R.Br., Prodr. (1810) 509.

Type: 'Grose [River], first branch', Brown [Bennett 2367] s.n., 'Dec 23, 1804' (Brown ms.)(BM, 3 sheets).

Prostanthera sp. aff. melissifolia sensu Beauglehole, Victorian Vasc. Pl. Checkl. (1980)173.

At least in part, probably based on: Beauglehole 31386, 31450, 33659, 32527 (refer Notes, below).

Prostanthera incisa sensu Ewart, Fl. Victoria (1931) 985

Possibly based on: 'Cape Howe Ranges, Vict.', Walter s.n., no date (MEL 43377).

Possible synonyms:

Prostanthera violacea sensu Ewart, Fl. Victoria (1931) 984, non R.Br. (1810).

Based on: Unknown. 
Prostanthera violaceae var. albiflora sensu Ewart, Fl. Victoria (1931) 984, ? non F. Muell. (1867).

Based on: Unknown.

Erect (fide MEL, Oct 1997), openly branched shrub, 2-2.5 $\mathrm{m}$ high, strongly and \pm unpleasantly aromatic; branches laterally ridged, moderately to densely covered with short, curled hairs, densely covered with subsessile glands. Leaves green, paler below, covered with short, curled hairs basally and along midrib of abaxial surface, densely covered with subsessile glands; petiole 3-10 mm long; lamina ovate, $15-30 \mathrm{~mm}$ long, 8-12 mm wide; base short- to long-attenuate and \pm decurrent, usually symmetric; margin \pm coarsely toothed with teeth directed forward to laterally; apex obtuse. Inflorescence a frondobracteose botryoid. Prophylls not persistent, c. $1 \mathrm{~mm}$ long, c. $0.2 \mathrm{~mm}$ wide. Calyx 4-5 mm long; tube c. $2 \mathrm{~mm}$ long; adaxial lobe c. $2 \mathrm{~mm}$ long (slightly enlarged in fruit). Corolla pale mauve to mauve, 7-10 $\mathrm{mm}$ long. Anthers with appendage greatly reduce, only slightly extended beyond anther locule, hence appearing absent, each locule with a tuft of basal narrowly triangular trichomes.

Flowering: September-November. Fruiting: November-December.

Victorian specimens examined: East Gippsland: About $2 \mathrm{~km}$ SE of Mt Carlyle summit, Albrecht 3625 \& Walsh, 4 Sep 1988 (MEL, NSW 451476); Howe Ranges, Beauglehole 31386, 30 Oct 1969 (AD 97209279); 31450, 1 Nov 1969 (AD 97209277); 33659, 8 Aug 1970 (AD 97209222); Mallacoota Inlet National Park, Beauglehole 32527, 16 Dec 1969 (AD 97209278); Cape Howe Range, Walter s.n., without date (MEL 43377); Howe Range, Willis s.n., 24 Oct 1948 (MEL 43372).

Distribution: Prostanthera incisa (s. lat.) occurs in the Central Tablelands, North Coast, Central Coast and South Coast regions of New South Wales, and is here extended to included the Howe Range populations (refer Fig. 4) of East Gippsland in Victoria.

Habitat: tall open forests dominated by Eucalyptus muelleriana, E. smithii and Callitris rhomboidea.

Vernacular name: cut-leaf Mint-bush (Ewart 1931, p. 985; Willis 1973, p. 588).

Notes: although Beauglehole (1980) did not cite any collections as vouchers of his informal name ' $P$. sp. aff. melissifolia', his reference to region ' $Z$ ' (namely, East Gippsland), suggests that he was referring to the Howe Range/Mallacoota National Park populations of this species.

Apart from distributional data, little is know about this taxon. Although these populations are morphologically very similar to P. melissifolia (at least in herbarium material), the leaves tend to be smaller and narrower than the latter. It is not entirely certain, but the Howe Range populations tend to be strongly aromatic, more typical of the known New South Wales populations of P. incisa and P. sieberi. Although variable, the prophylls tend to be inserted on the distal third of the podium, whereas those of $P$. melissifolia are inserted just below the calyx.

Studies into the systematics of the P. incisa-P. sieberi complex are necessary before the status of these Howe Range populations can be completely resolved.

\section{Acknowledgments}

I gratefully thank Margaret Corrick (joint collection of the type specimen of Prostanthera galbraithiae B.J.Conn) (then MEL) for her assistance in the field. Bonnie Thompson (South Traralgon) and Neville Walsh (MEL) generously provided advice on the conservation status of this species. Lesley Elkan (NSW) prepared the illustrations in this paper. I thank the Directors and Curators of the many herbaria for allowing me the opportunity of studying material in their care. 


\section{References}

Beauglehole, A.C. (1980) Victorian Vascular Plant Checklists - 13 - Study Area and 24 - Grid Distribution. (Western Victorian Field Naturalists Clubs Association: Portland).

Bentham, G. (1834) Labiatarum genera et species. (James Ridgway and Sons: London).

Bentham, G. (1870) Flora Australiensis, vol. V (L. Reeve \& Co.: London).

Brown, R. (1810) Prodromus floræ Novæ Hollandix et Insulæ Van-Diemen. (J. Johnson \& Co.: London).

Buchanan, A.M. (1988) The Tasmanian collecting localities of Ronald Gunn \& Joseph Milligan. Tasmanian Herb. Occas. Publ. No. 1: 1-56

Buchanan, A.M. (1990) Ronald Campbell Gunn 1808-1881. Pp. 179-192 in Short, P.S. (ed.) History of Systematic Botany in Australasia. (Australian Syst. Bot. Soc. Inc.: South Yarra).

Chapman, A. (1991) Australian Plant Name Index K-P. (Australian Govt. Publ. Serv.: Canberra).

Conn B.J. (1984) A taxonomic revision of Prostanthera Labill. section Klanderia (F.v. Muell.) Benth. (Labiatae). J. Adelaide Bot. Gard. 6: 207-348.

Conn, B.J. (1992) Lamiaceae. Pp. 623-664 in Harden, G.J. (ed.). Flora of New South Wales, vol. 3 (New South Wales University Press: Kensington).

Conn, B.J. (1993) Natural regions and vegetation of Victoria. Pp. 79-158 in Foreman, D.B. \& Walsh, N. (eds), Flora of Victoria, vol. 1 (Inkata Press: Melbourne).

Conn, B.J. (1995) Description of inflorescence axes in the genus Logania R.Br. (Loganiaceae). Kew Bull. 50: 777-783.

Ewart, A.J. (1931) Flora of Victoria. (Government Printer: Melbourne).

Fowler, H.W. (1965) A Dictionary of Modern English Usage, revised by E. Gowers (Oxford Univ. Press: Oxford).

Hooker, J.D. \& Jackson, B.D. (1894) Index Kewensis, part III (Clarendon Press: Oxford).

Mueller, F.[J.H.] (1867) Fragmenta Phytographix Australix, vol. VI (Auctoritate gubern. coloniæ Victoriæ: Melbourne).

Sealy, J.R. (1948) Prostanthera melissifolia var. parvifolia - Labiatae. t. 9687 in Cotton, A.D. (ed.), Curtis's Botanical Magazine, vol. 164.

Willis, J.H. (1973) A Handbook to Plants in Victoria, vol. II Dicotyledons. (Melbourne Univ. Press: Carlton).

Manuscript received 11 August 1997

Manuscript accepted 16 January 1998 